\title{
Morphological Integration of Urdu Loan Words in Pakistani English
}

\author{
Tania Ali Khan ${ }^{1}$ \\ ${ }^{1}$ Minhaj University/Department of English Language \& Literature Lahore, Pakistan \\ Correspondence: Tania Ali Khan, Minhaj University/Department of English Language \& Literature Lahore, \\ Pakistan
}

Received: March 19, 2020

Accepted: April 18, 2020

Online Published: April 21, 2020

doi: 10.5539/elt.v13n5p49

URL: https://doi.org/10.5539/elt.v13n5p49

\begin{abstract}
Pakistani English is a variety of English language concerning Sentence structure, Morphology, Phonology, Spelling, and Vocabulary. The one semantic element, which makes the investigation of Pakistani English additionally fascinating is the Vocabulary. Pakistani English uses many loan words from Urdu language and other local dialects, which have become an integral part of Pakistani English, and the speakers don't feel odd while using these words. Numerous studies are conducted on Pakistani English Vocabulary, yet a couple manage to deal with morphology. Therefore, the purpose of this study is to explore the morphological integration of Urdu loan words in Pakistani English. Another purpose of the study is to investigate the main reasons of this morphological integration process. The Qualitative research method is used in this study. Researcher prepares a sample list of 50 loan words for the analysis. These words are randomly chosen from the newspaper "The Dawn" since it is the most dispersed English language newspaper in Pakistan. Some words are selected from the Books and Novellas of Pakistani English fiction authors, and concise Oxford English Dictionary, 11th edition. The results show that, when the Urdu language loan words are morphologically integrated in Pakistan English, they do not change their grammatical category. Moreover, four distinguished morphological process are identified in integration of these loan words. The results also reveal that deficit hypothesis is the main reason of this lexical borrowing
\end{abstract}

Keywords: integration, loan words, morphology, Pakistan English, Urdu language

\section{Introduction}

The English language is known as an international language, since this language has attained a position, where it is highlighting many social jobs, which are perceived and recognized by each nation. English language is the language of the whole globe on account of its unnecessary use in communication. This language stretched its wings in different countries of the world, during the time of postcolonial, and human race witnessed the powerful gravity of the English language. As Kachru said that English is no longer the property of British and American; in-fact, it is the language which uses it. (Bilal, Warraich, Fatima, Tiwana \& Bhatti, 2012)

This scenario has made the English language a shared property of the entire world. As, this language is incorporating with different dialects and languages, and the locals began to blend or include their own local language's words in the English language, since than diverse local varieties of the English language are coming into existence. And all of these varieties are special in their particular systems. Pakistani English is one of the broadly used postcolonial variety in the world of English languages. According to Raza, Pakistan is among the list of nations, where English language is spreading quickly. Eighteen million individuals of the overall population of Pakistan are communicating in English, and the figures are rising each day, which makes Pakistan the third biggest English speaking Asian country. (Raza, 2008)

Rehman said, that like other local varieties of English language, Pakistani English likewise has four sub-varieties, and these are SBE (identical to Standard English), Acrolect, Mesolect, and Bisolect. (Rehman, 1990) Pakistani English uses a decent number of loan words due to the influence of the local languages. (Bilal et al., 2012) These words have become an integral part of Pakistani English. It is relatively a complicated variety of English language, due to its rich and diverse linguistics map. Unluckily, this unique variety is less researched in terms of etymology, morphology, and syntax. (Mehboob \& Kortmann, 2004)

To comprehend morphological integration process of loan words, which is less debated and researched, it is fundamental to understand the analytical framework of morphology. Linguistics views integration as an 
asymmetric process. Linguists think integration as a non-productive and non-transformational process. It chiefly centers around dialects. When two dialects interact with one another, their association triggers uneasiness and threat to national identity and issues like linguistics solidarity or corruption. (Fragkopoulou, 2015) In linguistics, integration is a subject of discussion under all domains. Therefore, there are various kinds of integration processes.

a) Phonological integration

b) Morphological integration

c) Orthographic integration

d) Syntactic integration

e) Semantics integration

f) Pragmatics integration

The present paper considers morphological integration, which makes it obligatory to comprehend the systematic structure of morphology. There are various depictions of morphology, yet these mirror a similar thought as "Morphology is the grammar of words, which includes the formation of words, the structure of words, and relationship between the words". (Audring \& Masini, 2018)

Also, morphological integration implies "Restructuring the loan words morphology and phonology based on the morphology and phonology of the recipient language”. (Campbell, 2004)

The past studies uncover that, when dialects interact with different dialects, this interaction prompts changes in the stock of one or either languages. (Matras, 2009) Predominately the beneficiary language uncovers extraordinary and unique features that influence the loan words. The loan word is one of the most used morphological word-formation processes. (Islam, 2011) Campbell characterized loan word as, "A lexical thing, which obtained from a source language, that lexical item is initially not a part of the vocabulary of the beneficiary language; however it received from a source language and turned into a part of the beneficiary language's vocabulary". (Campbell, 2004)

The language which donates its words to the other language is known as donor language, and the one which gets new words is known as beneficiary language.

Morphological integration occurs, when speaker of one language tries to speak a different language with influence of his first language. Then, speaker borrows the words from his first language, which he needs to use, in order to fulfill his daily chores, and integrates them in the second language. This fact is relatable to the expansion of Pakistani English vocabulary and also to the other varieties of English language. (Bilal et al., 2012) This evident diversity makes it so important to understand the morphological information of these emerging varieties of English language. The researcher takes this initiative to investigate Pakistani English and explain the morphological pattern of these integrated loan words.

\subsection{Research Objectives}

The present study has these research objectives:

1. To find out the morphological procedures use in the integration of Urdu loan words in Pakistani English.

2. To highlight the variables, affecting the morphological integration of Urdu loan words in Pakistani English.

\subsection{Research Questions}

The present investigation is addressing the following inquiries:

1. What morphological procedures Pakistani English uses in the integration of Urdu loan words?

2. What are the variables affecting the morphological integration of Urdu loan words in Pakistani English?

\subsection{Research Gap}

There are numerous studies, that discussion about the use of loan words in Pakistani English. However; this fact can't be ignored that not all of the loan words used in Pakistani English precisely in the same way as they did in the source language. In-fact, these words are used in beneficiary language after applying the integration process. Studies are available on morphological integration in Dutch and Arabic languages only; however, in the Pakistani context, there is an absence of adequate and exact studies, which makes this research gap a contextual research gap. Therefore, this research is an attempt to fill this contextual gap by exploring the morphological procedures which are used in the integration of the loan words in Pakistani English context. 


\subsection{Delimitations}

There are different types of integration, as mentioned above, but researcher delimited the current study to the morphological integration of loan words, and to the discussion about the elements which are affecting these word formation processes. Due to, the absence of etymological dictionaries and lack of research works, the facts provided in this paper delimited to the available online dictionaries.

\section{Literature Review}

"Morphology is the word-grammar. It includes word type, structure, its context, relationships between the words, and the forms in which new and complex words are formed". Depending on these views, the aim of morphological is either to account for all the existing words or any potential words of a language. Hence, morphological integration means "Restructuring the loan words morphology and phonology in the beneficiary language, based on the morphology and phonology of the recipient language". (Audring \& Masini, 2018)

Many studies stated that, In order to enhance the vocabulary, languages either make up new words by integrating the phonological or morphological structure of the already existing words or by borrowing some words from other languages and integrate them in new structure. In case of Pakistani English, the most noticeable process which is enhancing the Pakistani English dictionary is borrowing. Pakistani English has borrowed a lot of significant and different words from Urdu and other local languages. Other morphological word-formation processes contribute to integrate the vocabulary of Pakistani English, but the contribution made by these word-formation processes cannot be overlooked. These word formation processes are transformation, Semantic move, Maintenance, and many others. (Mehboob \& Kortmann, 2004)

Baumgardner, Kennedy, and Shamim in (1993) presented 54 classifications, in which words are acquired from local languages into the English language. These classifications were edibles, religion, peace, wedding, customs, apparel, artistry, music, and so on. (Bilal et al., 2012) In the matter of Pakistani English, the vast majority of the loan words have taken from the areas of edibles, dress, religion, government organization, legislative issues, workmanship, custom, and many others. Furthermore, this borrowing has enhanced the Pakistani English lexicon as well as, it has affected the grammar of Pakistani English also. (Baumgardner, 1993)

The Urdu language is the national language of Pakistan, and it is vastly affecting the Pakistani English vocabulary. The reason behind this impact is the unusual contact of Urdu language with Pakistani English. Consequently, Pakistani English vocabulary is experiencing the process of Urduization. (Tallat, 2003)

Baumgardner observed Pakistani English and derived that a decent number of loan words from Urdu and other provincial dialects has recorded in Pakistani English. Besides this, in word formation-processes, prefixes and suffixes played a beneficial and creative job in enhancing Pakistani English vocabulary. (Bilal et al., 2012)

Kachru stated that South Asian Englishes use hybridized structure in words that emphasizes the novelty and productiveness of south Asian varieties of English. In this hybridization process, one word of local language is joined by the other word of English language, or sometimes one syllable of the local language is combined by the one syllable of the English language, for example, Lathi charge, Rickshaw driver, Tonga driver, police-wala, and so on. (Kachru, 1983)

Tallat drew attention to the significant attributes of Pakistani English that when loan words are used in Pakistani English by Pakistani bilingual speakers, they contain their Urdu meanings. (Tallat, 2003) In (1994) Kachru proposed two hypotheses which are the cause of lexical borrowing in languages, and these two hypotheses are deficit hypothesis and dominance hypothesis.

Deficit hypothesis stated that "Borrowing entails linguistics gaps in a language and the prime motivation for borrowing is to alleviate the linguistics deficit, especially in the lexical resources of a language".

This theory brought into the light this fact that, speakers of a language borrow a word from another language mainly because they don't have a similar word in their language. The sole reason behind this sort of lexical borrowing is to fill the linguistics gap. Dominance hypothesis stated that "when two cultures come into contact, then direction of culture learning and subsequent word-borrowing will lead from dominant to the subordinate." Speakers do not borrow words to fill the linguistics gap, but to show the novelty of the particular language. (Dashti \& Dashti, 2017)

On the subject of Pakistani English, it came into notice, that speakers used loanword to fill the semantics gap since they don't have a similar term in the English language. As a result, this lexical acquiring in Pakistani English mainly falls under the category of deficit hypothesis. In (1993) Kennedy did an investigation on "Use of Lexical Terms in crime reporting in Pakistan." He discovered that Pakistani print media uses more nostalgic and 
agitated words in reporting in comparison to American media. These words have adjusted new meanings, which are specific to the Pakistani context of crime reporting. Besides this, Pakistani print media coined many compound words. These words have no substitutions in American or British English. (Jackson, 1993)

Fragkopoulou in (2015) presented a wide range of opinions of different researchers about morphological integration of loan words Bloomfield (1933), Hoffmann (1991), Filipović (1980,1981,1995), Van Marle (1993) and Romaine (2010) stated that morphological integration of the loan words is not a haphazard process, but it is a steady and gradable procedure. In fact this is a process which involves three different degrees of integration. These degrees are total integration, partial integration, and zero integration. (Poplack \& Sankoff, 1984)

It means, when language loans a word, the degree of morphological integration gives the detail of the diffusion of the words. A borrowed item can be represented in the beneficiary language phonological, morphological, and syntactical system as well (i.e., as code-switches), yet the possibility of recurrence of an item in beneficiary language increased the chances of the high diffusion of that word in the structure of new language (become genuine loanwords). It refers as a graduality assumption. (Poplack \& Dion, 2012)

\section{Methodology}

The nature of the current study is qualitative and it is a corpus-based study. To find out the answer of the first question, the researcher prepared a sample list of 50 selected loan words for the analysis. For this purpose, the researcher used different sources, like the daily newspaper "The Dawn" of months May and June, books and novellas of Pakistani English fiction authors, and a concise Oxford English dictionary, the eleventh version revised in the year 2006. These fifty loan words divided into four different tables. Table 1 based on the Urdu loan words used in Pakistani English with some changes. This tables composed of 20 words. Table 2 contained of 10 Urdu loan words used in Pakistani English without changes. Table 3 covered 10 Urdu loan words used in international English with changes. Table 4 again covered10 Urdu loan words used in international English without changes.

In order to find the answer of the second question the researcher applied the proposed theory of Kashru's two Hypothesis (Dominance hypothesis \& Deficient hypothesis) to know the variables, which are affecting the morphological integration of loan words in Pakistani English.

Table 1. Urdu loan word used in Pakistani English with changes

\begin{tabular}{ccc}
\hline No & Loan words & Meanings \\
\hline 1 & Mela & A fair or a festival \\
2 & Kebab & A dish of pieces of meat roasted or grilled on a skewer or spit \\
3 & Majlis & A gathering of people \\
4 & Nawab & An Indian ruler during Mogul empires \\
5 & Sufism & The mystical system or a school of practice that emphasizes the inward \\
& search for God and shuns materialism \\
6 & Whahabism & A fraternity in Islam \\
7 & Hijabism & A cultural tradition loved and respect by Muslims females of wrapping a \\
& piece of cloth around their head. \\
8 & Desism & Being local or following or admiring local traditions \\
9 & Pakistani & People of Pakistan \\
10 & Lahori & People of Lahore \\
11 & Punjabi & People of province Punjabi \\
12 & Bookie & A person who determines gambling odds and receives and pays off bets \\
13 & Nikkah ceremony & In ceremony in which bride and groom under the rules of Islam sign a \\
& & marriage contract in front of some witness. \\
14 & Janazah prayer & Funeral prayer \\
15 & Shaadi halls & Marriage halls \\
16 & Rikshaw stand & Auto stand \\
17 & Gym khana & Gymnasium \\
18 & Chai studio & Tea studio \\
19 & Pind road & Village road \\
20 & Ghora street & Horse street \\
\hline & &
\end{tabular}


Table 2. Urdu loan word used in Pakistani English without changes

\begin{tabular}{ccc}
\hline No & Urdu loan words & Meanings \\
\hline 1 & Shariah & Islamic law \\
2 & Tonga wala & Coach man \\
3 & Basant & A festival celebrated at the arrival of spring season \\
4 & Biryani & A dish of spice rice and meat \\
5 & Pulao & A dish of saltish rice and meat \\
6 & Haji & People who perform Hajj \\
7 & Kabbadi & Name of a sport \\
8 & Qawali & A style of Muslim devotional music now associated particularly \\
& Dupatta & with Sufis. \\
9 & Shalwar & A long piece of cloth used by female. \\
10 & A traditional style of loose trousers. \\
\hline
\end{tabular}

Table 3. Urdu loan words used in global English with changes

\begin{tabular}{|c|c|c|}
\hline No & Urdu loan words & Meanings \\
\hline 1 & Cushy & Soft \\
\hline 2 & Bangle & An ornamental band worn on the wrist or arm \\
\hline 3 & Cot & A small bed for a young child \\
\hline 4 & Bunglow & A one-story house \\
\hline 5 & Dungaree & Trousers held up by straps over the shoulders. \\
\hline 6 & Loot & Steal goods from a place, typically during a war or riot \\
\hline 7 & Blighty & $\begin{array}{c}\text { Britain or England, as used by soldiers serving abroad in the first } \\
\text { and second World Wars." }\end{array}$ \\
\hline 8 & Cheroot & $\begin{array}{l}\text { A dried tobacco leaf is cut and rolled in a particular way, it } \\
\text { becomes a cigar with both ends open }\end{array}$ \\
\hline 9 & Dekko & Used In Britain's informal English 'dekko' means a quick glance \\
\hline 10 & Copra & Dried coconut kernels \\
\hline
\end{tabular}

Table 4. Urdu loan words used in global English without changes

\begin{tabular}{ccc}
\hline No & Urdu loan words & Meanings \\
\hline 1 & Halal & $\begin{array}{r}\text { Denoting or relating to meat prepared as prescribed by Muslim law. } \\
\text { Area of town where there are many small shops }\end{array}$ \\
3 & Bazar & $\begin{array}{c}\text { An area of land overgrown with dense forest and tangled vegetation } \\
\text { A seasonal prevailing wind in the region of South and SE Asia, } \\
\text { blowing from the south-west between May and September and } \\
\text { bringing rain }\end{array}$ \\
& Moon soon & A sash worn around the waist \\
5 & Cummer bund & A soft white fibrous substance which surrounds the seeds of the \\
6 & Cotton & cotton plant and is made into textile fiber and thread for sewing, \\
& textile fabric made from cotton fiber \\
7 & Chita & A specie of lion \\
8 & Garam masala & Mixture of spices \\
9 & Khaki & Dust color \\
10 & Pajamas & Loose comfortable dress use to wear during night \\
\hline
\end{tabular}

\section{Analysis and Result}

This morphological integration analysis will elevate the following morphological features.

- The etymology of the loan words.

- Grammatical category (GM) of the word in donor (Urdu) language 
- Grammatical category (GM) of loan word in beneficiary (Pakistani English) language.

- Type of the morpheme used in changing of the grammatical category of word

- Level of integration of loan word. (Primary, Partial \& Total)

- Use of Morphological process

- The motivation of the Lexical borrowing (Deficit hypothesis/Dominance hypothesis)

Table 5. Urdu loan word used in Pakistani English with changings

\begin{tabular}{|c|c|c|c|c|c|c|c|c|c|}
\hline No & $\begin{array}{l}\text { Loan } \\
\text { words }\end{array}$ & Etymology & $\begin{array}{l}\text { GM in } \\
\text { Urdu }\end{array}$ & $\begin{array}{l}\text { GM in } \\
P E\end{array}$ & $\begin{array}{l}\text { Free/Bound } \\
\text { Morpheme }\end{array}$ & $\begin{array}{l}\text { Lexical/Functional } \\
\qquad v \text { s } \\
\text { Derivational } \\
\text { /Inflectional }\end{array}$ & $\begin{array}{l}\text { Level of } \\
\text { Integration }\end{array}$ & $\begin{array}{c}\text { Morphological } \\
\text { Process }\end{array}$ & $\begin{array}{l}\text { Reason of } \\
\quad \text { lexical } \\
\text { Borrowing }\end{array}$ \\
\hline 1 & Mela & $\begin{array}{c}\text { Sanskrit } \\
1682\end{array}$ & Noun & Noun & Bound & Inflection /s/ & Primary & Suffixation & $\begin{array}{c}\text { Deficit } \\
\text { hypothesis }\end{array}$ \\
\hline 2 & Kebab & $\begin{array}{l}\text { Persian } \\
1602\end{array}$ & $\begin{array}{c}\text { Noun \& } \\
\text { adjective }\end{array}$ & Noun & Bound & Inflection /s/ & Primary & Suffixation & $\begin{array}{c}\text { Deficit } \\
\text { hypothesis }\end{array}$ \\
\hline 3 & Majlis & $\begin{array}{l}\text { Arabic } \\
1602\end{array}$ & $\begin{array}{c}\text { Noun \& } \\
\text { adjective }\end{array}$ & Noun & Bound & Inflection /s/ & Primary & Suffixation & $\begin{array}{c}\text { Deficit } \\
\text { hypothesis }\end{array}$ \\
\hline 4 & Nawab & $\begin{array}{c}\text { Arabic } \\
1800\end{array}$ & $\begin{array}{l}\text { Noun \& } \\
\text { adjective }\end{array}$ & Noun & Bound & Inflection /s/ & Primary & Suffixation & $\begin{array}{c}\text { Deficit } \\
\text { hypothesis }\end{array}$ \\
\hline 5 & Sufism & $\begin{array}{c}\text { Arabic } \\
\text { (sufi) } 1564\end{array}$ & Noun & Noun & Bound & Derivational /ism/ & Partial & Suffixation & $\begin{array}{c}\text { Deficit } \\
\text { hypothesis }\end{array}$ \\
\hline 6 & Whahabisn & Arabic & Adjective & Noun & Bound & Derivational /ism/ & Partial & Suffixation & $\begin{array}{c}\text { Deficit } \\
\text { hypothesis }\end{array}$ \\
\hline 7 & Hijabism & $\begin{array}{c}\text { Arabic } \\
\text { (hijab) } \\
1611\end{array}$ & Noun & Noun & Bound & Derivational /ism/ & Partial & Suffixation & $\begin{array}{c}\text { Deficit } \\
\text { hypothesis }\end{array}$ \\
\hline 8 & Desism & $\begin{array}{c}\text { Sanskrit } \\
\text { (desi) } 1700\end{array}$ & Adjective & Noun & Bound & Derivational /ism/ & Partial & Suffixation & $\begin{array}{c}\text { Deficit } \\
\text { hypothesis }\end{array}$ \\
\hline 9 & Pakistani & $\begin{array}{c}\text { Persian } \\
\text { (Pakistan) } \\
1933\end{array}$ & Adjective & Adjectivı & Bound & Derivational /i/ & Primary & Suffixation & $\begin{array}{c}\text { Deficit } \\
\text { hypothesis }\end{array}$ \\
\hline 10 & Lahori & $\begin{array}{l}\text { Hindi } \\
\text { (Lahore) }\end{array}$ & Adjective & Adjectivı & Bound & Derivational /i/ & Primary & Suffixation & $\begin{array}{c}\text { Deficit } \\
\text { hypothesis }\end{array}$ \\
\hline 11 & Punjabi & Persian & Adjective & Adjectivı & Bound & Derivational /i/ & Primary & Suffixation & $\begin{array}{c}\text { Deficit } \\
\text { hypothesis }\end{array}$ \\
\hline 12 & Bookie & Hindi & Noun & Noun & Nil & Nil & Nil & Nil & $\begin{array}{c}\text { Deficit } \\
\text { hypothesis }\end{array}$ \\
\hline 13 & $\begin{array}{l}\text { Nikkah } \\
\text { ceremony }\end{array}$ & $\begin{array}{l}\text { Arabic } \\
\text { (Nikkah) } \\
\text { English } \\
\text { (ceremony) }\end{array}$ & Noun & Noun & Free & Lexical & Nil & $\begin{array}{l}\text { Hybridization } \\
\text { compounding }\end{array}$ & $\begin{array}{c}\text { Deficit } \\
\text { hypothesis }\end{array}$ \\
\hline 14 & $\begin{array}{l}\text { Janazah } \\
\text { prayer }\end{array}$ & $\begin{array}{c}\text { Persian } \\
\text { (Janazah) } \\
\text { English } \\
\text { (prayer) }\end{array}$ & Noun & Noun & Free & Lexical & Nil & $\begin{array}{l}\text { Hybridization } \\
\text { compounding }\end{array}$ & $\begin{array}{c}\text { Deficit } \\
\text { hypothesis }\end{array}$ \\
\hline 15 & Shaadi hal] & $\begin{array}{l}\text { Perisn } \\
\text { (Shaadi) }\end{array}$ & Noun & Noun & Free & Lexical & Nil & $\begin{array}{l}\text { Hybridization } \\
\text { compounding }\end{array}$ & $\begin{array}{c}\text { Deficit } \\
\text { hypothesis }\end{array}$ \\
\hline
\end{tabular}




\section{Hall}

(English)

16

Rikshaw Japanese

stand

(Riksahw)

Noun

Noun

Free

Lexical

Nil

Hybridization

Deficit

Stand

(English )

17 Gym khanء
English

Noun

Noun

Free

Lexical

Nil

Hybridization

compounding

Deficit

(Gym)

Perisn

(Khana)

1564

18

\section{Chai studic Persian}

(Chai)

Noun

Noun

Free

Lexical

Nil

Studio

(English)

19

Pind road

Punjabi

(pind)

Road

(English)

Noun

Noun

Free

Lexical

Nil

Hybridization

Deficit

compounding

hypothesis

$\begin{array}{cc}\text { Ghora } & \text { Sanskrit } \\ \text { street } & \text { (Ghora) } \\ & \text { Street } \\ & \text { English }\end{array}$

1. Melas, this word came in the Urdu language from the Sanskrit language in 1682. This word retained its meaning and grammatical category in the Urdu language. Pakistani English borrowed this word from the Urdu language. Both languages use this word as a common noun. But in case of pluralization of this word, bound inflectional morpheme $/ \mathrm{s} /$ is used at the end of the word to form the plural of this common noun.

$/$ Mela $+\mathrm{s} /=/$ Melas/.

The suffixation process is involved in the morphological integration of this word, and the level of morphological integration is primary, because, the meaning and grammatical category of the item remain the same with the addition of bound morpheme $/ \mathrm{s} /$. This addition just convert singular noun into a plural noun. The reason for this lexical borrowing is that, in the English language, there was not an equivalent term. Therefore, this lexical borrowing falls in the category of deficit hypothesis.

2. Kebabs, this word came in the Urdu language from the Persian language in 1603. The Urdu language uses this word as a noun and adjective. Pakistani English borrowed this word from the Urdu language. Pakistani English uses it as a noun. In case of pluralization of this word, bound inflectional morpheme $/ \mathrm{s} /$ is used at the end of the word to form the plural of this common noun /Kebabs/.

$/ \mathrm{Kebab}+\mathrm{s} /=/$ Kebabs/

The suffixation process is involved in the morphological integration of this word, and the level of morphological integration is primary. Because the word retains its meaning and one grammatical category noun, not adjective in Pakistani English. The addition of bound morpheme /s/ does not affect the grammatical category of the word. This addition just convert singular noun into a plural noun. The reason for this lexical borrowing is that, in the English language, there was not an equivalent term. Therefore, this lexical borrowing falls in the category of deficit hypothesis.

3. Majlis, this word came in the Urdu language from the Arabic language in 1602. Like the previous word, the Urdu language uses it as a noun and adjective. Pakistani English borrowed this word from the Urdu language and uses it as a noun. The plural of this word is formed by adding bound inflectional morpheme $/ \mathrm{s} /$ at the end of the word.

/Majlis+s/=/Majliss/ 
The suffixation process is involved in the morphological integration of this word, and the level of morphological integration is primary. The reason for this lexical borrowing is that, in the English language there was not an equivalent term. Therefore, this lexical borrowing falls in the category of deficit hypothesis.

4. Nawab, this word came in the Urdu language from the Arabic language in 1800. The Urdu language uses this word as a noun and adjective. Pakistani English borrowed this word from the Urdu language and uses it as a noun. The plural of this word is formed by adding bound inflectional morpheme $/ \mathrm{s} /$ at the end of the word.

$/ \mathrm{Nawab}+\mathrm{s} /=$ /Nawabs/

The suffixation process is involved in the morphological integration of this word, and the level of morphological integration is primary. The reason for this lexical borrowing is that, in the English language, there was not an equivalent term. Therefore, this lexical borrowing comes under the category of deficit hypothesis.

5. Sufism, this word came in the Urdu language from the Arabic language (Sufi) in 1564. This Urdu language uses this word as a noun. Pakistani English borrowed this word from the Urdu language.

/Sufi+ism/=/Sufism/

The suffixation process is involved in the morphological integration of this word. This word uses derivational bound morpheme (ism) in the end, and the level of morphological integration is partial. The reason for this lexical borrowing is that, in the English language, there was not an equivalent term. Therefore, this lexical borrowing falls in the category of deficit hypothesis.

6. Whahabism, this word came in the Urdu language from the Arabic language (Whahabi). The Urdu language uses this word as a noun. Pakistani English borrowed this word from the Urdu language.

/Whahab + ism/=/Whahabism/

The suffixation process is involved in the morphological integration of this word. Derivational bound morpheme (ism) is used in the end of this word and the level of morphological integration is partial. This reason for this lexical borrowing is that, in the English language, there was not an equivalent term. Therefore, this lexical borrowing falls in the category of deficit hypothesis.

7. Hijabism,this word came in the Urdu language from the Arabic language (hijab) in 1611. The Urdu language uses this word as a noun. Pakistani English borrowed this word from Urdu language.

/Hijab+ism/=/Hijabism/

The suffixation process is involved in the morphological integration of this word. This word uses derivational bound morpheme (ism) in the end, and the level of morphological integration is partial. The reason for this lexical borrowing is that, in the English language, there was not an equivalent term. Therefore, this lexical borrowing falls in the category of deficit hypothesis.

8. Desism, this word came in the Urdu language from the Sanskrit language (Desi) in 1700. The Urdu language uses this word as an Adjective. Pakistani English borrowed this word from Urdu language.

/Desi + ism/=/Desism/

The suffixation process is involved in the morphological integration of this word. This word uses derivational bound morpheme (ism) in the end, to change its grammatical category. And the level of morphological integration is partial. The reason for this lexical borrowing is that, in the English language, there was not an equivalent term. Therefore, this lexical borrowing falls in the category of deficit hypothesis.

9. Pakistani is the Persian language word used as an adjective in Persian language in 1933. The Urdu language uses this word as an Adjective as well. Pakistani English borrowed this word from the Urdu language.

/Pakistan $+\mathrm{i} /=/$ Pakistani/

The suffixation process is involved in the morphological integration of this word. This word takes derivational bound morpheme (i) in its end, to change the grammatical category, and the level of morphological integration is primary. The reason for this lexical borrowing is that, in the English language, there was not an equivalent term. Therefore, this lexical borrowing fall in the category of deficit hypothesis.

10. Lahori, a Hindi language word used as an adjective in the Hindi language. The Urdu language uses this word as Adjective. Pakistani English borrowed this word from the Urdu language.

$/$ Lahore $+\mathrm{i} /=/$ Lahori/ 
The suffixation process is involved in the morphological integration of this word. This word takes derivational bound morpheme (i) in its end, to change the grammatical category, and the level of morphological integration is primary. The reason for this lexical borrowing is that, in the English language, there was not an equivalent term. Therefore, this lexical borrowing falls in the category of deficit hypothesis.

11. Punjabi, a Persian language word used as an adjective in the Persian language. The Urdu language uses this word also as an Adjective. Pakistani English borrowed this word from the Urdu language.

/Punjab $+\mathrm{i} /=$ Punjabi/

The Suffixation process is involved in the morphological integration of this word. This word takes derivational bound morpheme (i) in the end to change the grammatical category, and the level of morphological integration is primary. The reason for this lexical borrowing is that, in the English language, there was not an equivalent term. Therefore, this lexical borrowing falls in the category of deficit hypothesis.

12. Bookie, a Hindi language word uses a as noun in the Urdu language. Pakistani English borrowed this word from the Urdu language. The reason for this lexical borrowing is that, in English language there was not an equivalent term. Therefore, this lexical borrowing falls in the category of deficit hypothesis.

13. Nikkah is an Arabic word and, Ceremony is an English word. Both vocabulary items are the nouns in their respective source languages. Pakistani English uses these two words uniquely as a compound noun, but this is a hybridized compounding. Both words are free lexical morphemes, and by joining them, they make up a new word. The reason for this lexical borrowing is that, in Pakistani English, there was not an equivalent term. Therefore, this lexical borrowing comes under the category of deficient hypothesis.

14. Janazah is a Persian word and, Prayer is an English word. Both Vocabulary items are the nouns in their respective source languages. Pakistani English uses these two words uniquely as a compound noun, but this is a hybridized compounding. Both words are free lexical morphemes, and by joining them, they make up a new word. The reason for this lexical borrowing is that, in Pakistani English, there was not an equivalent term. Therefore, this lexical borrowing comes under the category of deficient hypothesis.

15. Shaadi is a Persian word and Hall is an English word. Both words are the nouns in their respective source languages. Pakistani English uses these two words uniquely as a compound noun, but this is a hybridized compounding. Both words are free lexical morphemes, and by joining them, they make up a new word. The reason for this lexical borrowing is that, in Pakistani English, there was not an equivalent term. Therefore, this lexical borrowing comes under the category of deficient hypothesis.

16. Rikshaw is a Japanese word and, Stand is an English word. Both words are the nouns in their respective source languages. Pakistani English uses these two words uniquely as a compound noun, but this is a hybridized compounding. Both words are free lexical morphemes and by joining them, they make up a new word. The reason for this lexical borrowing is that, in Pakistani English, there was not an equivalent term. Therefore, this lexical borrowing comes under the category of deficient hypothesis.

17. Gym is an English word and Khana is a Persian language word. Both words are the nouns in their respective source languages. Pakistani English uses these two words uniquely as a compound noun, but this is a hybridized compounding. Both words are free lexical morphemes, and by joining them, they make up a new word. The reason for this lexical borrowing is that, in Pakistani English, there was not an equivalent term. Therefore, this lexical borrowing comes under the category of deficient hypothesis.

18. Chai is a Persian language word, and Studio is an English language word. Both words are the nouns in their respective source languages. Pakistani English uses these two words uniquely as a compound noun, but this is a hybridized compounding. Both words are free lexical morphemes, and by joining them, they make up a new word. The reason for this lexical borrowing is that, in Pakistani English, there was not an equivalent term. Therefore, this lexical borrowing comes under the category of deficient hypothesis.

19. Pind is a Punjabi language word, and Road is an English word. Both words are the nouns in their respective source languages. Pakistani English uses these two words uniquely as a compound noun, but this is a hybridized compounding. Both words are free lexical morphemes, and by joining them, they make up a new word. The reason for this lexical borrowing is that, in Pakistani English, there was not an equivalent term. Therefore, this lexical borrowing comes under the category of deficient hypothesis.

20. Gora is the Sanskrit language word, and Street is an English word. Both words are the nouns in their respective source languages. Pakistani English uses these two words uniquely as a compound noun, but this is a hybridized compounding. Both words are free lexical morphemes, and by joining them, they make up a new 
word. The reason for this lexical borrowing is that, in Pakistani English, there was not an equivalent term. Therefore, this lexical borrowing comes under the category of deficient hypothesis.

Table 6. Urdu loan word used in Pakistani English without changings

\begin{tabular}{|c|c|c|c|c|c|c|}
\hline No & $\begin{array}{l}\text { Urdu Loan } \\
\text { Words }\end{array}$ & Etymology & $\begin{array}{l}\text { GM in } \\
\text { Urdu }\end{array}$ & $\begin{array}{l}\text { GM in } \\
P E\end{array}$ & $\begin{array}{c}\text { Morphological } \\
\text { Process }\end{array}$ & $\begin{array}{c}\text { Reason of Lexical } \\
\text { Borrowing }\end{array}$ \\
\hline 1 & Shariah & $\begin{array}{c}\text { Arabic } \\
1421\end{array}$ & Noun & Noun & Direct Borrowing & Deficit hypothesis \\
\hline 2 & Tonga wala & Sanskrit & Noun & Noun & Direct Borrowing & Deficit hypothesis \\
\hline 3 & Basant & $\begin{array}{c}\text { Sanskrit } \\
1611\end{array}$ & Noun & Noun & Direct Borrowing & Deficit hypothesis \\
\hline 4 & Biryani & $\begin{array}{c}\text { Persian } \\
1832\end{array}$ & Noun & Noun & Direct Borrowing & Deficit hypothesis \\
\hline 5 & Pulao & $\begin{array}{c}\text { Persian } \\
1700\end{array}$ & Noun & Noun & Direct Borrowing & Deficit hypothesis \\
\hline 6 & Haji & $\begin{array}{c}\text { Arabic } \\
1564\end{array}$ & Adjective & Adjective & Direct Borrowing & Deficit hypothesis \\
\hline 7 & Kabbadi & $\begin{array}{c}\text { Parakat } \\
1846\end{array}$ & Noun & Noun & Direct Borrowing & Deficit hypothesis \\
\hline 8 & Qawali & $\begin{array}{c}\text { Arabic } \\
1837\end{array}$ & Noun & Noun & Direct Borrowing & Deficit hypothesis \\
\hline 9 & Dupatta & $\begin{array}{c}\text { Persian } \\
1421\end{array}$ & Noun & Noun & Direct Borrowing & Deficit hypothesis \\
\hline 10 & Shalwar & $\begin{array}{l}\text { Persian } \\
1697\end{array}$ & Noun & Noun & Direct Borrowing & Deficit hypothesis \\
\hline
\end{tabular}

1. Shariah word came in the Urdu language from the Arabic language in 1421. The Urdu language uses this word as a Noun. Pakistani English borrowed this word from the Urdu language, and uses it as a noun. The reason for this lexical borrowing is the deficit hypothesis.

2. Tonga Wala word first used in the Sanskrit language, and it came in the Urdu language as a noun. Pakistani English directly borrowed this word from the Urdu language, and the reason for this lexical borrowing is the deficit hypothesis.

3. Basant is the word of the Sanskrit language. It came in the Urdu in 1611 as a noun, and Pakistani English uses this word also as a noun, and the reason for this lexical borrowing is the deficit hypothesis.

4. Biryani is the Persian word came in the Urdu language in 1832 as a noun, and Pakistani English directly borrowed this word. Deficit hypothesis became the reason for this lexical borrowing.

5. Pulao word first used in the Persian language, later the Urdu language borrowed it as a noun in 1700 . And Pakistani English borrowed this word from the Urdu language, and the reason for this lexical borrowing is the deficit hypothesis.

6. Haji is the Arabic word came in the Urdu language in 1564 as a noun. And Pakistani English borrowed this word from the Urdu language. Deficit hypothesis became the reason for this lexical borrowing.

7. Kabbdi is the Parakat language word. It came in the Urdu language in 1846 as a noun, and Pakistani English uses this word also as a noun, and the reason for this lexical borrowing is the deficit hypothesis.

8. Qawali is the Arabic word. The Arabic language used it as a noun. The Urdu language directly borrowed this word as a noun. And now, Pakistani English uses it, and the reason for this borrowing is the deficit hypothesis.

9. Dupatta word first used in the Persian language in 1421 and, it came in the Urdu language as a noun. Pakistani English directly borrowed this word, and the reason for this lexical borrowing is the deficit hypothesis. 
10. Salwar word first used in the Persian language, and it came in the Urdu language in 1697 as a noun. Pakistani English directly borrowed this word, and the reason for this lexical borrowing is the deficit hypothesis.

Table 7. Urdu loan words used in global English with changes

\begin{tabular}{|c|c|c|c|c|c|c|c|c|c|}
\hline No & $\begin{array}{l}\text { Urdu loan } \\
\text { words }\end{array}$ & Etymology & $\begin{array}{l}\text { GM in } \\
\text { Urdu }\end{array}$ & $\begin{array}{l}\text { GM in } \\
P E\end{array}$ & $\begin{array}{c}\text { Free } \\
\text { /bound } \\
\text { morpheme }\end{array}$ & $\begin{array}{c}\text { Lexical/Functional } \\
\text { VS } \\
\text { Inflectional/Derivational }\end{array}$ & $\begin{array}{l}\text { Level of } \\
\text { Integration }\end{array}$ & $\begin{array}{c}\text { Morphological } \\
\text { process }\end{array}$ & $\begin{array}{c}\text { Reason of } \\
\text { lexical } \\
\text { borrowing }\end{array}$ \\
\hline 1 & $\begin{array}{l}\text { Cushy } \\
\text { (Kushi) }\end{array}$ & Persian & Noun & Adjective & Free & Lexical & Total & $\begin{array}{c}\text { Modification } \\
\text { of vowel and } \\
\text { consonant }\end{array}$ & $\begin{array}{l}\text { Dominance } \\
\text { hypothesis }\end{array}$ \\
\hline 2 & $\begin{array}{l}\text { Typhoon } \\
\text { (Toofaan) }\end{array}$ & Urdu & Noun & Noun & Free & Lexical & Total & $\begin{array}{c}\text { Modification } \\
\text { of vowel and } \\
\text { consonant }\end{array}$ & $\begin{array}{c}\text { Deficit } \\
\text { hypothesis }\end{array}$ \\
\hline 3 & $\begin{array}{c}\text { Cot } \\
\text { (Khaat) }\end{array}$ & Urdu & Noun & Noun & Free & Lexical & Total & $\begin{array}{l}\text { Modification } \\
\text { of vowel and } \\
\text { consonant }\end{array}$ & $\begin{array}{c}\text { Deficit } \\
\text { hypothesis }\end{array}$ \\
\hline 4 & $\begin{array}{l}\text { Bunglow } \\
\text { (Bangla) }\end{array}$ & Urdu & Noun & Noun & Free & Lexical & Partial & $\begin{array}{l}\text { Modification } \\
\text { of vowel and } \\
\text { consonant }\end{array}$ & $\begin{array}{c}\text { Deficit } \\
\text { hypothesis }\end{array}$ \\
\hline 5 & $\begin{array}{l}\text { Dungaree } \\
\text { (Dangree) }\end{array}$ & Urdu & Noun & Noun & Free & Lexical & Partial & $\begin{array}{c}\text { Modification } \\
\text { of vowel and } \\
\text { consonant }\end{array}$ & $\begin{array}{c}\text { Deficit } \\
\text { hypothesis }\end{array}$ \\
\hline 6 & $\begin{array}{l}\text { Loot } \\
\text { (Loot) }\end{array}$ & Urdu & $\begin{array}{l}\text { Noun \& } \\
\text { verb }\end{array}$ & $\begin{array}{l}\text { Noun \& } \\
\text { verb }\end{array}$ & Free & Lexical & Nil & $\begin{array}{c}\text { Direct } \\
\text { Borrowing }\end{array}$ & $\begin{array}{c}\text { Deficit } \\
\text { hypothesis }\end{array}$ \\
\hline 7 & $\begin{array}{c}\text { Veranda } \\
\text { (Baramda) }\end{array}$ & Hindi & Noun & Noun & Free & Lexical & Partial & $\begin{array}{c}\text { Modification } \\
\text { of vowel and } \\
\text { consonant }\end{array}$ & $\begin{array}{c}\text { Deficit } \\
\text { hypothesis }\end{array}$ \\
\hline 8 & $\begin{array}{l}\text { Thug } \\
\text { (Thag) }\end{array}$ & Urdu & Adjective & Adjective & Free & Lexical & Primary & $\begin{array}{l}\text { Modification } \\
\text { of vowel }\end{array}$ & $\begin{array}{c}\text { Deficit } \\
\text { hypothesis }\end{array}$ \\
\hline 9 & $\begin{array}{l}\text { Punch } \\
\text { (Panch) }\end{array}$ & Urdu & $\begin{array}{c}\text { Countable } \\
\text { noun/ } \\
\text { Nominal }\end{array}$ & Noun & Free & Lexical & Partial & $\begin{array}{l}\text { Modification } \\
\text { of vowel }\end{array}$ & $\begin{array}{c}\text { Deficit } \\
\text { hypothesis }\end{array}$ \\
\hline 10 & $\begin{array}{c}\text { Copra } \\
\text { (Khopra) }\end{array}$ & Sanskrit & Noun & Noun & Free & Lexical & Primary & $\begin{array}{l}\text { Modification } \\
\text { of consonant }\end{array}$ & $\begin{array}{l}\text { Dominance } \\
\text { hypothesis }\end{array}$ \\
\hline
\end{tabular}

1. Kushi word came in the Urdu language from the Persian language. The Urdu language uses this word as a Noun. The Global English borrowed this word from the Urdu language. The Global English uses this word as Cushy, which is an adjective. In the integration of this word, modification morphological process is used, and vowels and consonants sounds of the word were modified. The level of integration is total. The reason for this lexical borrowing into the global English is the dominance hypothesis.

2. Toofaan is a purely the Urdu language word. Urdu language uses this word as a noun. The Global English borrowed this word from the Urdu language. The Global English uses this word as Typhoon, which is a noun. In the integration of this word, modification morphological process is used and, vowels and consonants sounds of the word were modified. The level of integration is total. The reason for this lexical borrowing into the global English is the deficit hypothesis.

3. Khaat is the Urdu language word. The grammatical category of this word is the noun. The Global English borrowed this word from the Urdu language, and uses it as Cot, which is also a noun. In the integration of this word, modification morphological process is used and, vowels and consonants sounds of the word were modified. The level of integration is total. The reason for this lexical borrowing into the global English is the deficit hypothesis.

4. Bangla is the Urdu language word. The grammatical category of this word is the noun. The Global English borrowed this word from the Urdu language, and uses it as Bunglow, which is also a noun. In the integration of this word, modification morphological process is used, and, vowels and consonants sounds of the word were 
modified. The level of integration is partial. The reason for this lexical borrowing into the global English is the deficit hypothesis.

5. Dangree is the Urdu language word. The grammatical category of this word is the noun. The Global English borrowed this word from the Urdu language, and uses it as Dungaree, which is also a noun. In the integration of this word, modification, morphological process is used, and the level of integration is partial. The reason for this lexical borrowing into the global English is the deficit hypothesis.

6. Loot is the Urdu language word. The grammatical category of this word is the noun and verb. The Global English directly borrowed this word from the Urdu language, and uses it as Loot, which also function as a noun and verb. This word is not morphological integrated, but phonetic integration is involved in this word. Therefore, the level of integration is zero in this word. The reason for this lexical borrowing into the global English is the deficit hypothesis.

7. Baranmda is the Hindi language word. The grammatical category of this word is noun. The Urdu language borrowed this word from the Hindi language. This word went into the Global English from the Urdu language, and the global English uses it as Veranda, which is also a noun. In the integration of this word, modification, morphological process is used and, vowels and consonants sounds of the word were modified. The level of integration is total. The reason for this lexical borrowing into the global English is the dominance hypothesis.

8. Thag is the Urdu language word. The grammatical category of this word is adjective. The Global English borrowed this word from the Urdu language, and uses it as Thug, which is also a noun. In the integration of this word, modification morphological process is used, and only vowel sound of the word was modified. The level of integration is primary. The reason for this lexical borrowing into the global English is the deficit hypothesis.

9. Panch is the Urdu language word. The grammatical category of this word is the nominal noun. The Global English borrowed this word from the Urdu language, and uses it as Punch, which is a noun. In the integration of this word, modification morphological process is used, and only vowel sound of the word was modified. The level of integration is partial. The reason for this lexical borrowing into the global English is the deficit hypothesis.

10. Khopra is the Sanskrit language word. The grammatical category of this word is the noun. The Global English borrowed this word from the Urdu language, and uses it as Copra, which is also a noun. In the integration of this word, modification morphological process is used, and only consonant sound of the word was modified. The level of integration is primary. The reason for this lexical borrowing into the global English is the dominance hypothesis.

Table 8. Urdu loan words used in global English without changes

\begin{tabular}{|c|c|c|c|c|c|c|}
\hline No & Urdu loan words & Etymology & $\begin{array}{l}\text { GM in } \\
\text { Urdu }\end{array}$ & $\begin{array}{l}\text { GM in } \\
P E\end{array}$ & $\begin{array}{c}\text { Morphological } \\
\text { process }\end{array}$ & $\begin{array}{c}\text { Reason of Lexical } \\
\text { Borrowing }\end{array}$ \\
\hline 1 & Halal & $\begin{array}{c}\text { Arabic } \\
1635\end{array}$ & Adjective & Adjective & Direct Borrowing & Deficit hypothesis \\
\hline 2 & Bazar & $\begin{array}{c}\text { Persian } \\
1421\end{array}$ & Noun & Noun & Direct Borrowing & Dominance hypothesis \\
\hline 3 & Jungle & $\begin{array}{c}\text { Sanskrit } \\
1611\end{array}$ & Noun & Noun & Direct Borrowing & Dominance hypothesis \\
\hline 4 & Moon soon & Urdu & $\begin{array}{c}\text { Noun \& } \\
\text { Adjective }\end{array}$ & Noun & Direct Borrowing & Deficit hypothesis \\
\hline 5 & Cummer bund & Persian & Noun & Noun & Direct Borrowing & Dominance hypothesis \\
\hline 6 & Cotton & Urdu & Noun & Noun & Direct Borrowing & Deficit hypothesis \\
\hline 7 & Chita & $\begin{array}{c}\text { Sanskrit } \\
1503\end{array}$ & $\begin{array}{c}\text { Noun \& } \\
\text { adjective }\end{array}$ & $\begin{array}{c}\text { Noun \& } \\
\text { Adjective }\end{array}$ & Direct Borrowing & Dominance hypothesis \\
\hline 8 & Garam masala & $\begin{array}{l}\text { Arabic and } \\
\text { Persian }\end{array}$ & Noun & Noun & Direct Borrowing & Deficit hypothesis \\
\hline 9 & Khaki & Persian & Noun & Noun & Direct Borrowing & Dominance hypothesis \\
\hline 10 & Pajamas & $\begin{array}{c}\text { Persian } \\
1778\end{array}$ & Noun & Noun & Direct Borrowing & Dominance hypothesis \\
\hline
\end{tabular}


1. Halal word came in the Urdu language from the Arabic language in 1635. In Urdu language, this word is used as an adjective. Pakistani English borrowed this word from the Urdu language. Pakistani English uses this word as an adjective. The Urdu language directly borrowed this word from the Arabic, and Pakistani English borrowed this word directly form the Urdu language. Now this word is also used in global English as well. The reason for this lexical borrowing is the deficit hypothesis.

2. Bazar word first used in the Persian language, and it came in the Urdu language in 1421 as a noun. Pakistani English directly borrowed this word, and now this word is also used in global English. In global English, there are other similar words, but the reason for this lexical borrowing is the dominance hypothesis.

3. Jungle is the word of the Sanskrit language. It came in the Urdu in 1611 as a noun, and Pakistani English uses this word also as a noun. From Pakistani English, this word is directly borrowed in global English, and the reason for this lexical borrowing is the dominance hypothesis.

4. Moon soon is purely the Urdu language word uses as a noun and adjective in the Urdu language. Global English directly borrowed this word from Pakistani English, and deficit hypothesis became the reason for this lexical borrowing.

5. Cummerbund word first used in the Persian language, later the Urdu language borrowed it as a noun. Now, the global English also uses this word. In global English, there are other similar words, but the reason for this lexical borrowing is the dominance hypothesis.

6. Cotton is purely the Urdu language word, uses as a noun. The Global English directly borrowed this word from Pakistani English, and deficit hypothesis became the reason for this lexical borrowing.

7. Chita is the Sanskrit language word, it came in the Urdu language in 1503 as a noun and adjective, and Pakistani English uses this word also as a noun and adjective. From Pakistani English, this word is directly borrowed by global English and the reason for this lexical borrowing is the dominance hypothesis.

8. Garam masala is the Arabic and the Persian word. In both languages, this word is used as a noun. The Urdu language directly borrowed this word as a noun. And now, it is also used in the global English and the reason for this borrowing is the dominance hypothesis.

9. Khaki word first used in the Persian language, and it came in the Urdu language as a noun. Pakistani English directly borrowed this word and now, the global English also uses this word. In global English, there are other similar words, but the reason for this lexical borrowing is the dominance hypothesis.

10. Pajamas word first used in the Persian language, and it came in the Urdu language in 1778 as a noun. Pakistani English directly borrowed this word, and now the global English also uses this word. In global English, there are other similar words, but the reason for this lexical borrowing is the dominance hypothesis.

\subsection{Morphological Processes used in the Integration of Loan Words}

In response to the first research question, the current study reveals that, loan words retain their grammatical category in the Pakistani English. These loan words employed four distinguished morphological processes in their integration into Pakistani English. These four distinguished morphological processes are Suffixation, Hybridization compounding, Direct borrowing and Modification. The results also unveil that the integration of these loan words is gradable. Loan words which used suffixation morphological process were primary and partially integrated into Pakistani English. In suffixation morphological process loan words used both derivational and inflectional bound morphemes of English language in the end. Bound inflectional morpheme (s) is used to form the plural of the particular word. And derivational bound morphemes (i, ism) of English language are used to retain the grammatical category of the loan word in Pakistani English. The loan words which used hybridization compounding process were not integrated at all. Loan words which used direct borrowing morphological process were also not integrated at all. In fact these words became part of the global English and the global English started to use them without any change. Whereas, Loan words which used modification process were totally, partially or primary integrated into Pakistani English. In modification process the loan words integrated their vowels and consonants sound. Even some loan words modified their meaning as well.

\subsection{Variables Influencing the Morphological Integration of Loan Words}

In response to the second research question, the current study reveals that the variable which is affecting the morphological integration of loan words is the deficit hypothesis. The speakers borrow loan words from Urdu and other local languages into Pakistani English, because Pakistani English is lacking in specific area of vocabulary. To fill this linguistics gap the speaker borrow the forms of Urdu language into Pakistani English. In borrowing process, the behavior of the speakers is another very important factor. There are two categories of 
language behavior of the speakers, negative and positive attitude. In case of Pakistani English, words are borrowed from Urdu and other local languages with positive attitude, because the sole intention behind this borrowing is to fill the linguistics gap, which shows the inadequacy of vocabulary items in Pakistani English. The speakers give a new or acceptable structure to a loan word, to make it sound like English language. Therefore, they use integration process and change the very structure of the particular item according to Pakistani English.

It also came into notice that, some words are borrowed in Pakistani English, because of the influence of the dominance hypothesis. Despite the fact that, those words already exist in English language, but speakers use other forms of Urdu and local languages just to highlight the linguistics appreciation. They users portray competence, modern thoughts, and openness of Urdu language and culture toward English language.

With regard to linguistics variable, the most influential variable is the nature of the loanword. When this question comes, what morphological pattern a specific loan word will use to adjust, or to integrate itself, in a new system of a target language. The answer comes from the structure and the generative tendency of the particular loan word in the target language. Instead of the structure of the loan word, the system of the recipient language is also very significant because the very structure of the recipient language will help to predict the integration and modification of the loan word in the new system of the recipient language. This account establishes the fact that not only the nature of the loan word but also the productive nature of the recipient language is also very significant to predict or to understand the morphological integration of words in any language. It shows the generative and dynamic nature of the recipient language. It has been seen during the analysis, that each word integrates itself according to its tendency and uses a specific morphological pattern to adjust its self in the new environment of Pakistani English.

\section{Conclusion and Recommendations}

Therefore, this study concludes that, Pakistani English uses many loan words from Urdu and other local languages. The present investigation only talks about particular morphological attributes found in the fifty selected Urdu loan words. These results have established this fact that loan words are an integral part of Pakistani English, which makes Pakistani English a unique variety of English language. The results also reveal that Pakistani English is catering the needs of its speakers and helping them to perform better in the daily communication. Pakistani English is showing very appreciative attitude not only towards local language but also towards other foreign languages by absorbing their words into its new and supportive environment. This paper helps in understanding and specifying the unique features of morphological processes used in the integration of these selected Urdu loan words. The study is an attempt to fill the contextual research gap. This study suggests to compile the etymological dictionaries of loan words, which include the origin and morphological development of the loan words to increase the interest of the new researchers in this area. Because of the absence of the etymological lexicons, it was hard for the researcher to give unambiguous information about the origin of Urdu loan words used in Pakistani English. Many words of the Pakistani English became part of global English vocabulary, which is a significant characteristic, yet there is no hint of their history and information. This research limits itself to the variables, which are affecting the morphological integration of the loan words in Pakistani English. There is a need to conduct more studies on morphological integration in various different dialects of Pakistani English, to fill this contextual gap.

\section{References}

Audring, J. \& Masini, F. (2018). The Oxford Handbook of Morphological Theory. Oxford: Oxford University press.

Baumgardner, J. (1993). The English language in Pakistan. Karachi: Oxford University press. https://doi.org/10.1093/oxfordhb/9780199668984.001.0001

Bilal, H. A., Warraich, A. A., Fatima, N., Tiwana, D. S. \& Bhatti, T. R. (2012). Urdu Loan-Words in Pakistani English. Global Journal of Human Social Science Linguistics \& Education, 12(9), 1-7.

Bilal, H. A., Warraich, A. A., Fatima, N., Tiwana, D. S. \& Bhatti, T. R. (2012). Loan Words of Urdu in Standard English. Asian Journal of Social Science \& Humanitites, 1(2), 1-12.

Campbell, L. (2004). Historical Linguistics: An introduction. Edinburgh: Edinburgh University Press.

Crystal, D. (2003). English as a Global Language. Cambridge: Cambridge University Press. https://doi.org/10.1017/CBO9780511486999 
Dashti, F. \& Dashti, A. A. (2017). Morphological Adaptation of English Loanwords in Twitter: Educational Implications. International Journal of Higher Education, 6(1), 1-18. https://doi.org/10.5430/ijhe.v6n3p231

Fragkopoulou, K. (2015). On Gradualness of Morphological Integration of Loanwords in Heptanesian. Geek Linguistics, 12(1), 1-34.

Hafez, O. (1996). Phonological and Morphological Integration of Loanwords into Egyptian Arabic. Open Edition Journals, 6 (26), 1-23. https://doi.org/10.4000/ema.1958

Islam, R. A. (2011). The Morphology of Loanwords in Urdu: the Persian, Arabic and English Strands. PhD dissertation submitted to Newcastle University.

Jackson, R. (1993). Crime Reporting in Pakistani English. Karachi: Oxford University Press.

Matras, Y. (2009). Language Contact. Cambridge: Cambridge University Press. https://doi.org/10.1017/CBO9780511809873

Mehboob, A. \& Kortmann, B. (2004). Pakistani English: Morphology and Syntax. A Handbook of varieties of English: A multimedia reference tool. New York: Mouton de Gruyter.https://doi.org/10.1515/9783110175325.2.1045

Poplack, S. \& Dion, N. (2012). Myths and Facts about Loanword Development. Language Variation and Change, 24(3), 279-315. https://doi:10.1017/S095439451200018X

Poplack, S. \& Sankoff, D. (1984). Borrowing the Synchrony of Integration. Linguistics, 22, 99-135.https://doi.org/10.1515/ling.1984.22.1.99

Raza, W. (2008). Patterns in Pakistani English: Pronunciation and Pedagogic Priorities. Market Forces, 4(3), 102-112.

Rehman, T. (1990). Pakistani English. Islamabad: Quaid-i- Azam University Press.

Tallat, M. (2003). Pakistani English: A Sociolinguistic Variety. Journal of Research, 4, 17-30.

\section{Copyrights}

Copyright for this article is retained by the author(s), with first publication rights granted to the journal.

This is an open-access article distributed under the terms and conditions of the Creative Commons Attribution license (http://creativecommons.org/licenses/by/4.0/). 